\title{
Study of Learning Strategy Integration of Science and Religion on the Development of Student Character
}

\author{
Abdulkadir Rahardjanto \\ University of Muhammadiyah Malang \\ rahardjanto@gmail.com
}

\author{
Retno Susilowati \\ Maulana Malik Ibrahim State Islamic University of Malang \\ retnosusilowatibms@gmail.com
}

\begin{abstract}
The purpose of education in Indonesia is to form a complete Indonesian man. It entirely means that human development requires a balance between the cognitive, affective, psychomotor, and religious domains. Religion cannot be separated from the development of one's personality, because in essence man in the world is to live and worship God. Learning science is basically a digging, review, disclosure, understanding on research symptoms, structures, and functions of nature around which then brought into the classroom as learning activities with scientific rules that are commonly developed. This activity is not an independent activity, but it is a scientific activity associated with the belief in the greatness of the creator for the development of student character. Position of student character development is very important before the scientific education is done.This research was conducted for 1 semester by using sample of 49 students who took course of plant ecology. The purpose of this research is to understand the development of student character by studying nature based on Islamic religion. The research method was analyzed by RapRiCons with modification, and with multi-dimensional scaling (MDS) which was then followed by Monte Carlo analysis. The results showed that learning strategies by integrating religion and science showed a positive increase in student character.
\end{abstract}

Keywords: Learning strategy, integration religion and science, RapRiCons, Multi-dimensional scaling, Monte Carlo analysis.

\section{INTRODUCTION}

The outcome of an education can be understood in everyday life including the characters that are presented to each individual. Education is practiced in everyday life, such as a small activity to open the door for others [11]. Plenary education is education that can be practiced in real life, not limited to knowledge alone, has become habit, behavior and individual character in their life [15].

Based on the definition issued by the Ministry of National Education Indonesia [19], [8], the character can be described as a good individual when a person knows virtue, has the willingness to do good deeds and behaves well, as a result of intellectual, spiritual and emotional development, healthy physical development, affective development and creativity, rooted in religious values, Indonesian national culture and responsive to the changing demands of the times.
Science education is an education that leads students to the understanding of nature through the five senses which is then processed on the framework of the conceptual field of science. Truth in Science is not only pointing at the evidence-based reasoning but also at making questions about identity, meaning, purpose, and belief [7], [2]. In Islamic rules, the understanding of nature is directed to the exaltation of the creator, Allah. The integration of this understanding is the embodiment of students' knowing and feeling skills in real life [15].

The character in Islam is one of the main values written in the Qur'an [13]. [11] uses term as old as Education itself. Achievement of good character can be done with the character education in school [21]. However, this Education will be better if is not only done at school [22], [18]. Character education in higher education must be maintained. This is supported by [5], that based on a holistic approach, character education must be done continuously. Education at the university level does not necessarily use a nationally proclaimed curriculum, however there are guidelines for curriculum development for universities called Higher Education Curriculum (HEC) based on the achievement of competencies to be achieved [9].

Unfortunately, currently not all of the subjects taught have integrated knowledge in the cognitive domain with understanding of affective and conative actions, in accordance with the demands that have been proposed by the college curriculum [9], [6], [12], [20]. One of the institution of religion-based university in Malang is University of Muhammadiyah Malang (UMM). The university has asserted that the character of the student needs to be established through Education because the character is not merely the concern of cognitive domain of education but it must be practiced in everyday life. In Islam there are 3 things emphasis Character education for human beings are: (1) Faith, (2) Charity and (3) good morals [17].Thus, Education is basically a learning that is capable of forming one's personality, doing good and right actions, by putting faith into the conscience.

The development of character education requires a model learning strategy in building the character of the students. This strategy specifically has its own character formation program integrated with all student activities. 
Model integration of science and religion in UMM is a learning strategy that needs to know its influence on student character. This integration has been done in the learning process at UMMbut has not revealed any research that relate to the development of student character.

\section{METHODS}

This study objective is to identify the model integration of science and religion as a tool for the development of cognitive and religious domains as the basis of faith in the felling of student characters in Islamic-based university. The subjects of the study were 49 students of $4^{\text {th }}$ semester. Research instruments to collect data were questionnaires and observation sheets. Indicators in the development of questionnaires are as follows: Descriptions of faith, good deeds and morals are described in 5 consecutive pillars: (1). the pillars of spiritual value, (2). the pillars of behavior, (3). the pillars of ethics, (4). the pillars of self-concept, and (5). the pillars of self-development.

These five pillars are the key words of character development of students. The integration model uses RAPRICons developed by Rahardjanto (2013) with modifications. RAPRiCons uses several sequence attributes to illustrate the assessment of several aspects, then set the binary scale. The ordination of a series of attributes is processed on a multi-dimensional scale (MDS) followed by scale and rotation process.

Root Mean Square (RMS) on $\mathrm{X}$ axis ordination will determine attribute sensitivity. On the $\mathrm{x}$ axis simulates the best judgment and worst [4] is simulated by choosing extreme attribute scores. The greater the value of RMS in an attribute will indicate that attributes have an increasing role in the development of student character. In another dimension, the Y-axis is activated to maintain the normality of the ordination on the second axis of the first axis. Significant differences will be demonstrated by the
Monte Carlo simulation of errors associated with the original assessment [1].

Monte Carlo analysis on MDS is used to analyze the effect of errors from the process that has been done. With a $95 \%$ confidence level. If there is a small difference between the results of the MDS analysis and the Monte Carlo index, it indicates that student character development is good with a 95\% confidence level. Conversely, if the value of the large difference, it indicates that the character development of students is not good.

Determination of stress value and coefficient of determination value $\left(\mathrm{R}^{2}\right)$ will reflect the accuracy of the studied dimension. This value reflects the functioning goodness of fit whether to add attributes or not to the MDS analysis. The value of determination $\left(\mathrm{R}^{2}\right)$ close to 1 indicates that the student character development is good and the stress value is less than $0.25(\mathrm{~S}<0.25)$.

\section{RESULT}

This index indicates that the 5 pillars used as a reference for the development of student character in the integration of science and religion show good results. The highest score on the spiritual value pillar of 70.02 is followed by the behavioral pillars 68,06 , ethics 64,17 , selfconcept 56,07, and the last is the self-development pillar 57,25 as in table 1 below. The results of this study indicate that integrating the values of religion in science learning can improve the development of good behavior, ethics, self-concept and self-development of students. On the other hands the role of lecturers in the lectures is to build a good integration of science and religion. The value of religious values is not separated from science, because basically studying nature is to study the verses of the creator.

Table 1. Result ofIntegration of Science and Religion to Develop student Character

\begin{tabular}{lllllll}
\hline Dimensional & $\begin{array}{l}\text { Character } \\
\text { Development }\end{array}$ & $\begin{array}{l}\text { MDS } \\
\text { Monte } \\
\text { Diferrence }\end{array}$ & $\begin{array}{c}\text { and } \\
\text { Carlo }\end{array}$ & Statistics Value & Iteration \\
& MDS & $\begin{array}{l}\text { Monte } \\
\text { Carlo }\end{array}$ & & Stress & R2 \\
\hline spiritual value Pillars & 70,12 & 70,19 & 0,07 & 0,19 & 0,93 & 2 \\
Behavior Pillars & 68,06 & 68,44 & 0,38 & 0,19 & 0,93 & 2 \\
Ethics Pillars & 64,17 & 64,12 & 0,05 & 0,21 & 0,91 & 3 \\
Self-concept Pillars & 56,07 & 56,50 & 0,43 & 0,22 & 0,90 & 3 \\
Self-development Pillars & 57,25 & 57,13 & 0,12 & 0,21 & 0,91 & 3 \\
\hline
\end{tabular}

Based on Table 1, each dimension has a value "stress" which is much smaller than the provision that states that the value of "stress" obtained value of $25 \%$. As the value of "stress" diminishes, it shows that the quality of the analyzes is getting better. In the contrary, to the coefficient of determination $\left(\mathrm{R}^{2}\right)$, the quality of the analysis becomes better if the value of the coefficient of determination is greater (approaching value 1). Thus, from all parameters, the value of "stress" and $\mathrm{R}^{2}$ indicate that all the attributes used in the development of the character of the student achieved good status.

This study uses Monte Carlo analysis to assess the total confidence index score in each dimension. After repeated analysis several times, Monte Carlo analysis shows errors that do not make much changes to the total index value and each dimension. Based on Table 1 it can be seen that the value of the student character development index has a 
coefficient of determination of $90 \%-93 \%$. these results indicate a small difference between the results of MDS analysis and Monte Carlo analysis. The small differences between student's character development index values between the MDS analysis method and the Monte Carlo analysis show the following: 1) errors in each pillar score are relatively small; 2) the assessment variation is relatively small because of the difference of respondent opinion, and 3) data entry errors and lost data can be avoided on the analysis performed.

In line with the opinion of [3] Character education is the essence of education that has been practiced since several centuries ago. This education leads to the excavation of a good value on life to complement the knowledge and skills acquired in the classroom [14]. The development of this good character is not only occurs in the religion of Islam, but also in Christianity [24].The development of student character can be done by habituation to study the value of religion in science learning. The activities of the students are to study the verses that are in accordance with the subject matter being studied, to appreciate differences of opinion at the time of discussion, to assist other students who have difficulty in the chapters studied.

\section{CONCLUSION}

Integrating science and religion is one of the development of student learning strategies that can be used to develop student character. Three advantages that can be achieved by using this strategy are: (1) increasing the understanding of religion for students; (2) deepening the field of value-based science; (3) the practice of science in everyday life. Thus, the development of students' good character can be rated with the daily behavior of students in the classroom or outside the classroom.

\section{REFERENCES}

[1] Alder J, Pitcher T.J., Preikshot D, Kaschner, Feriss, How good is good? A rapid Appraisal Technique for Evaluation of the Sustainability Status of fisheries of the North Atlantic. In Pauly and Pitcher (eds) "Methods for evaluation the impacts of fisheries on the North Atlantic ecosystem." Fisheries Research Report, 2000 Vol. 8 No.2.

[2] Barbour, I.,"When science meets religion: Enemies, strangers or partners?", HarperOne, 2000.

[3] Bialik M., Michael Bogan, Charles Fadel, Michaela Horvathova, "Character Education for the 21st Century: What Should Students Learn?" Center for Curriculum Redesign Boston, Massachusetts, 2015.

[4] Caharodin, J.B.A., Ermelinda Goc-Ong Tobias, Emma M. Sabado, Apolinario A. Alicante, Lucy B. Ledres, Olga M. Nuñeza, Domingo S. Ramirez, Participatory Rural Appraisal in the Upland Ecosystem of Mt. Malindang, Misamis Occidental, Philippines"In: SEARCA, S. (Ed.), Biodiversity
Research Programme (BRP) for Development in Mindanao: Focus on Mt. Malindang and Environs, Mindanao", Phillipines, 2004.

[5] Dharmawan, N. S., Implementasi pendidikan karakter bangsa pada mahasiswa di perguruan tinggi (implementing national character education to college students). "Paper presented at Pembinaan Pendidikan Karakter bagi Mahasiswa PTS di Lingkungan Kopertis Wilayah VIII", 2014.

[6] Febriyanti, "Kurikulum Pendidikan Tinggi Di Era Globalisasi (Pergeseran Dari Kurikulum Inti Dan Institusional Ke Kurikulum Berbasis Kompetensi)." TA’DIB, Vol. XVIII, No. 02, Edisi November 2013, 2013.

[7] Jacobsen D. \& Rhonda Hustedt Jacobsen, "Faith and Learning in a Post-Truth World". Journal of College \& Character VOLUME 19, No. 2, May 2018. 2018.

[8] Hidayati A., M.Zaim, Kasman Rukun, Darmansyah,"The Development Of Character Education Curriculum For Elementary Student In West Sumatera". International Journal of Education and Research Vol. 2 No. 6 June 2014, 2014.

[9] Kepmen, "Keputusan Menteri Pendidikan dan Kebudayaan Nomor 045/U/2002 Tentang Kurikulum Pendidikan Tinggi”, 2002.

[10] Larson K., "Understanding the Importance of Character Education (Thesis)". University of Wisconsin-Stout, 2009.

[11] Lickona, T., "Educating for character: How our school can teach respect and responsibility". New York City: Bantam,1991.

[12] Mas'ud A., "Pengembangan perangkat pembelajaran biologi Kurikulum Perguruan Tinggi (KPT) Berbasis KKNI di Program studi Pendidikan Biologi FKIP Universitas Khairun". Jurnal Pena Sains Vol. 1, No. 1, April 2014, 2014.

[13] Ministry of Religion, "Al-Qur'an dan Terjemahnya”, Jakarta: PT. Intermasa, 2000.

[14] Naval C., María Carmen González, Torres Aurora Bernal., Character Education International Perspectives. "Pedagogia e Vita Rivista di problemi pedagogici, educativi e didattici". Editrice la Scuola, 2015.

[15] Naqvi, S.M.R., "The Commencement of Character Education: A Religious Perspective". PJERE, June 2017, Vol. 2, No. 1, 2017.

[16] Novianti, N., "Bildungsroman for character education in higher education: An Indonesian context". International Journal of Education, 9(2), 126-132, 2017.

[17] Shihab, Q,M., "Membumikan Al Qur'an: Memfungsikan wahyu dalam kehidupan, Jilid II", Lentera Hati, Jakarta, 2010.

[18] Suherman, A., "The Implementation Of Character Education Values In Integrated Physical Education 
Subject In Elementary School". SHS Web of Conferences 42, 2018.

[19] Secretary of State of the Republic Indonesia, "Laws of The Republic Indonesia Number 20 Years 2003 About National Education System”. Jakarta, 2003.

[20] Suteja J., "Model-Model Pembelajaran Dalam Kurikulum Berbasis Kompetensi KKNI Di Perguruan Tinggi (Perubahan Dari Teacher Centered Learning KeArah Student Centered Learning)". Jurnal Edueksos Volume VI No 1, Juni 2017, 2017.

[21] Pattaro C., "Character Education: Themes and Researches. An Academic Literature Review". Italian Journal of Sociology of Education, 8(1), 630, 2016.
[22] Pala A., "The Need For Character Education". International Journal Of Social Sciences And Humanity Studies Vol 3, No 2, 2011.

[23] Rahardjanto A., Haryoto Kusnoputranto, Dwita Sutjiningsih, Francisia SSE Seda., The Ecological Perceptions and Communities Participations on River Conservation Based on Bioindicator Odonata Knowledge in Upper Watershed Area: A Case Study in Batu District, East Java, Indonesia. "Proceeding of The 4th International Conference on Sustainable Future for Human Security SUSTAIN 2013". Kyoto University. Japan, 2013.

[24] Wilhelm, G.M., "A comparative-qualitative research analysis of character education in the christian school and home education milieu". Thesis. Cedarville University, 2005. 